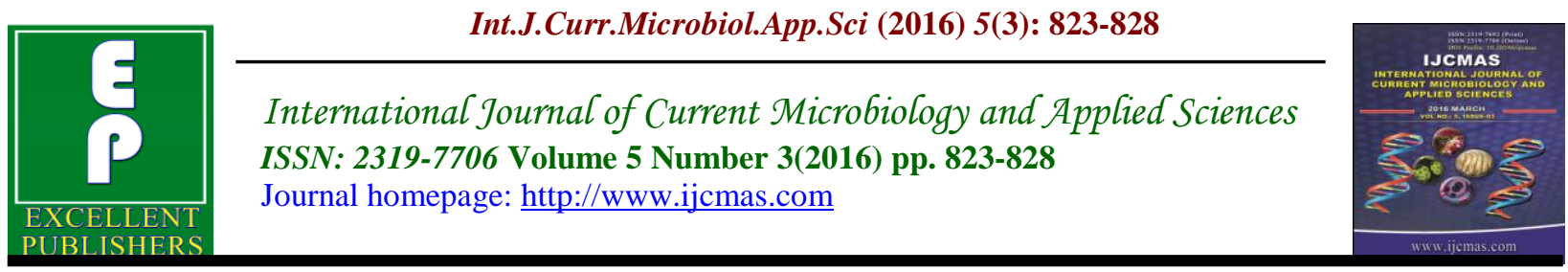

Review Article

http://dx.doi.org/10.20546/ijcmas.2016.503.095

\title{
Genomics Approaches Used to Control Plant Parasitic Nematodes - A Review
}

\author{
Shailendra Sharma* \\ Institute for Genomic Biology, Institute, University of Illinois, 1206 W. Gregory Dr., \\ Urbana, IL 61801, USA \\ *Corresponding author
}

\section{Keywords}

Plant parasitic nematodes (PPNs),

Genomics,

RNA interface

Article Info

Accepted:

15 February 2016

Available Online:

10 March 2016

\section{A B S T R A C T}

Plant parasitic nematodes (PPNs) are major pests in agriculture causing significant crop losses around the world. The overall damage due to PPNs was estimated at $\$ 157$ billion per annum (Abad et al 2008). These nematodes are distributed worldwide and have wide host range. Here we discus some latest biotechnology and genomics based approaches that can help in controlling plant parasitic nemated like root lesion nematodes (RLNs).

\section{Introduction}

Modern biotechnological tools are essential to combat against the plant parasitic nematodes. In modern functional genomics era some of the important tools that are being used by researchers are RNA interference (RNAi), microRNAs, transcriptome profiling, genome squencing etc. Besides these, transformation of cultivated species with cloned nematode resistance genes is another approach to create resistance (Jung und Wyss 1999). This strategy has the advantage to unify several resistance genes in one cultivar and thus to be able to build a notably wide and sustainable resistance.

Furthermore, resistance genes can be carried over by transformation to elite cultivars without transferring the negative qualities of the donor cultivar. Efforts are still going on to obtain transgenic plants for the abatement of nematodes of the genus Pratylenchus. However, enormous and successful progress was achieved in this area with other nematodes.Some of the strategies aimed at nematode targetsare(1) disruption of nematode intestine protease inhibitors or BT toxins antifeedant, nematicidal protein, (Enzyme inhibitors) (2) By triggering RNA interface (RNAi) to cause silencing of nematodes genes (3) By disruption of sensory functions with RNAi/ Peptide/ Plantibody and (4) by generation of nematicidal metabolites. Strategies aimed atthe plant-nematode interface are (1)disrupt nematodes pathogenicity factor, invasion and migration. (2) disrupt nematode pathogenicity factor- feeding site induction 
and maintenance (with RNAi and Plantibody, etc). (3) repellent plant and (4) conversion of plants to non-host.

One of the most common biotechnology based nematode management strategy is the expression of rice oryza cystatin protein, an inhibitor of cysteine proteases. Phytocystatins are low-molecular-weight proteins that have been isolated from a range of plants including seeds of soybean, corn, cowpea, chestnut, subepidermal cells of potato tubers, and tomato leaves overexpressing the wound-induced signal molecule prosystemin (Samac et al., 2003). Plant parasitic nematodes have been demonstrated to have multiple types of active proteases including cysteine proteases. Nematode intestinal proteases are attractive targets for disruption for several reasons (Lilley et al., 1996). Samac et al., (2003) have evaluated the resistance to the root-lesion nematode (Pratylenchus penetrans) in alfalfa (Medicago sativa) plants in which the cDNAs of the phytocystatins from rice were expressed under the control of the potato protease inhibitor II (PinII) promoter. To determine the pattern of gene expression from this promoter PinII-glucuronidase (GUS) gene was introduced into alfalfa plants. Leaf and root vascular tissue showed constitutive GUS expression.

In some plants, leaf mesophyll cells also showed expression. This GUS expression level was increased about two fold over 24 $\mathrm{hr}$ after mechanical wounding. To check the GUS expression level after nematode infestation, root lesion nematodes were inoculated to alfalfa transgenic and control transgenic plants. Localized GUS expression was observed after nematode inoculation. Reduced nematode population was recorded in alfalfa roots of transgenic plants in comparison to control transgenic line.
Two nematicides, 4-hydroxyphenylacetic acid (4-HPA)(1) and oidiolactone D (2), were isolated from cultures of the fungus Oidiodendron sp., and their structures were identified by spectroscopic analyses. Compound 2 showed nematicidal activities against the root-lesion nematode, Pratylenchus penetrans, and the pine wood nematode, Bursaphelenchus xylophilus. Compound 1 was also active against these two nematodes but to a lesser extent (Ohtani et al., 2011).

Here we discussed briefly RNAi and sequencing approaches that are being used to tackle the growing plant parasitic nematode populations. The RNA interference technology has proved to be particularly important to efficiently combat different species of root knot nematodes of the genus Meloidogyne both in vitro and in vivo (Huang et al., 2006). Classical studies in model nematode Caenorhabditis elegans (C.elegans) by Guo and Kemphues (1995) and Fire et al., (1998) laid the foundation of our present understanding of RNA interference (RNAi) technology. On plant side, earlier studies by Jorgensen et al., (1996) and Waterhouse et al., (1998) laid the foundation of modern day application of RNAi technology. RNAi involves the suppression of gene expression process by using sequence-specific, homologous RNA molecules. This mechanism is triggered by double-stranded RNA (dsRNA) that is further recognized by an enzyme called Dicer (Bernstein et al., (2001) Dicer processes the dsRNA to 21- to 26-nucleotide (nt) small dsRNA molecules known as siRNAs (short interfering RNAs). The DCR2R2D2 complex then binds to these small interfering RNA molecules (siRNAs) and then these small RNAs are then incorporated into a multisubunit complex called 'RNAinduced silencing complex' (RISC). Then this RISC directs the degradation of any 
endogenous mRNAs that are homologous to the small RNAs (Hammond et al., 2000; Novina and Sharp, 2004). Selection of target genes is quite crucial for the application of RNAi to control plant parasitic nematodes. Generally, target genes selected or silencing are those genes that either involved in (a) nematode development (b) parasitism and (c) mRNA metabolism. A detailed list of genes targeted and successful application of RNAi technology to control plant parasitic nemtodes is provided in a review article by Li et al., (2011). Useful target sequences for fruitful RNAi can also be detected by utilizing already available genome resources. Surplus information about lethal mutations and important specific genes is available in model nematode C.elegans. With the help of bioinformatics and comparative genomics one can study the corresponding homologs. This is more feasible for conserved genes. Alkharouf et al., (2007) and Ibrahim et al., (2011) recently applied this approach to identify interesting gene sequences in soybean cyst nematode i.e. Heterodera glycines. Interestingly, most of the reports of successful application of RNAi in plants are from sedentary nematodes. Such studies are lacking in migratory plant parasitic nematodes like root lesion nematodes, which is a big lacunae in understanding the mechanism of key genes involved in disease resistance at functional level. Efforts are needed in the direction to extend this fruitful technology. However, in such cases sequencing of essential genomic and EST sequences of plant-parasitic nematodes is useful. This will be quite helpful in understanding the key components involved in resistance towards root lesion nematodes. This has been demonstrated in a recent study in which transcriptome of the nematode Pratylenchus coffeae, a root lesion nematode, was studied through generating expressed sequence tags (ESTs) on a 454 sequencing platform (Hageman et al., 2011). In this study combination of different genomic approaches led to the identification of different sequences putatively involved in parasitism like different plant cell wall modifying enzymes. Surplus sequence information is also available from various nematode sequencing projects (Abad et al.,, 2008; Parkinson et al.,, 2004; McCarter et al.,, 2003). Several thousand ESTs were sequenced from 30 nematode species (Parkinson et al.,, 2004; McCarter et al.,, 2003). Besides, assisting in the identification of the key genes involved in parasitism, the genomic and EST sequences so generated could also provide clue to researchers to pinpoint appropriate target genes for RNAi experiments. Recently a report has been published by Tan et al., (2013) where they described the dsRNA mediated gene silencing in two important RLN species P. thornei and P.zeae. Artificial feeding silenced two important genes, calponin and troponin $\mathrm{C}$, essential for nematode structural integrity and proper muscle contraction.

The other major advantage of using sequence information is the identification and functional analysis of candidate effect or proteins. Numerous proteins are secreted into their host by plant-parasitic nematodes (Hageman et al., 2012). These proteins are known as effectors, have various functions in the plant cell. The function of many of these effectors is less clear or unknown (Hageman et al., 2012). Candidate parasitism proteins secreted by nematodes to modify plant tissues for parasitism includes cell-wall-modifying enzymes, multiple regulators of host cell cycle and metabolism, proteins that can localize to the plant cell nucleus, potential suppressors of host defense, mimics of plant molecules, and a relatively large cadre of predicted novel nematode parasitism proteins(Davis et al., 2008). These effectors are believed to have 
been acquired from bacteria or fungi by horizontal gene transfer (Hageman et al., 2012). One of the most important advancement in the field of nematology is the discovery that an arsenal of secretory proteins, with parasitism function, produced in the esophageal gland cells of root knot nematodes (Davis et al., 2000; Hussey 2011).Such studies are lacking in root lesion nematodes. However, bioinformatic analysis of available nematode genome sequences could help to identify the putative secreted proteins and subsequently to check their function as candidate effector. Very limited progress has been made so far in this direction. This field could be the new interesting area to work out for controlling plant parasitic nematode population by studying potential effector proteins in plant parasitic nematodes. Like other nematodes, it would be exciting to study biological role of novel candidate secreted parasitism proteins of root lesion nematodes. Sequencing of small RNAs like microRNAs (miRNAs) is another possibility needs to be explored in case of plant parasitic nematode. MicroRNAs have been found to be involved in a number of physiological and morphological processes. Therefore, it would be highly desirable to develop appropriate strategies and vector systems to study the involvement of small RNA molecules in parasitism.

In conclusion, it seems that different life style and physiological differences, even among the members of same species, made it highly difficult to develop a broad spectrum disease resistance against root lesion nematode in plants. Thelong term goal to achieve broad spectrum resistance can be only achieved by the proper and deep understanding of all the components involved in root lesion nematode plant interaction. It seems that modern functional genomic tools like RNAi and different sequencing platforms possess high potential to revolutionize the management of this category of plant pathogens especially in the cases where resistance genes are not yet discovered. In parallel, pursuit for natural resistance genes should be constantly done to develop natural root lesion nematode resistant crops. Search of genes/QTLs for root lesion nematode resistance through advanced mapping populations has been already demonstrated. Use of whole genome association mapping and high throughput genotypingsystem is a highly lucrative way to explore on large scale the diverse plant germplasm to discover novel resistance genes. Development of environmentally safe and cheap nematicides with broad range effect should also not be discouraged. Finally, one can say that participation of molecular plant breeding, genetic engineering and improved harmless chemical control methods is required for effective management of root lesion nematodes in plants.

\section{References}

Abad P, Gouzy J, Aury JM, CastagnoneSereno P, Danchin EG, Deleury E, Perfus-Barbeoch L, Anthouard V, Artiguenave F, Blok VC, Caillaud MC, Coutinho PM, Dasilva C, De Luca F, Deau F, Esquibet M, Flutre $\mathrm{T}$, Goldstone JV, Hamamouch N, Hewezi T, Jaillon O, Jubin C, Leonetti $\quad \mathrm{P}$, Magliano $\mathrm{M}$, Maier TR, Markov GV, McVeigh P, Pesole G, Poulain J, Robinson-Rechavi M, Sallet E, Ségurens B, Steinbach D, Tytgat T, Ugarte E, van Ghelder C, Veronico P, Baum TJ, Blaxter M, Bleve-Zacheo T, Davis EL, Ewbank JJ, Favery B, Grenier E, Henrissat B, Jones JT, Laudet V, Maule AG, Quesneville H, Rosso MN, Schiex T, SmantG, Weissenbach 
J, Wincker P (2008) Genome sequence of the metazoan plantparasitic nematode Meloidogyne incognita. Nature Biotech.26: 909-15.

Bakhetia M, Charlton W, Atkinson HJ, McPherson MJ (2005) RNA interference of dual oxidase in the plant nematode Meloidogyne incognita. Mol. Plant-Microbe Interact.18: 1099-1106.

BakhetiaM, Urwin PE, Atkinson HJ (2007)qPCR analysis and RNAi define pharyngeal gland cellexpressed genes of Heteroderaglycinesrequired for initial interactions with the host. Mol. PlantMicrobe Interact.20: 306-312.

Bernstein E, Caudy AA, Hammond SM, Hannon GJ (2001) Role for a bidentateribonuclease in the initiation step of RNA interference. Nature, 409:363-366.

Davis EL, Hussey RS, Baum TJ, Bakker J, Schots A (2000) Nematode parasitism genes. Annu

Rev

Phytopathol 38: 365-396

Davis EL, Hussey RS, Mitchum MG, Baum TJ (2008) Parasitism proteins in nematode-plant interactions. Curr.Opin. Plant Biol. 11: 360-366.

Fire A, Xu S, Montgomery MK, Kostas SA, Driver SE, Mello CC (1998) Potent and specific genetic interference by double-stranded RNA in Caenorhabditiselegans. Nature 391:806-11.

Guo S and Kemphues KJ (1995) par-1, a gene required for establishing polarity in C. elegansembryos, encodes a putative Ser/Thr kinase that is asymmetrically distributed. Cell. 81: 611-20.

Haegeman A, Joseph S, Gheysen G (2011) Analysis of the transcriptome of the root lesion nematode
Pratylenchuscoffeae generated by 454 sequencing technology. Molecular and Biochemical Parasitology 178: 714.

Haegeman A, Mantelin S, Jones JT, Gheysen G (2012). Functional roles of effectors of plant-parasitic nematodes.Gene 492: 18-31.

Hammond, SM, Bernstein E, Beach D, Hannon GJ (2000) An RNA-directed nuclease mediates post-transcriptional gene silencing in Drosophila cells. Nature 404: 293-296

Heba MM, Ibrahim, Nadim W,Alkharouf, Susan LF, Meyer, Mohammed AM,Aly, Y Abd El Kader, Ebtissam HA, Hussein, Benjamin F, Matthews (2011) Post-transcriptional gene silencing of root-knot nematode in transformed soybean roots. Exp. Parasitol. 127: 90-99

Huang G., R. Allen, E. L. Davis, T. J. Baum and R. S. Hussey, 2006: Engineering broad root-knot resistance in transgenic plants by RNA silencing of a conserved and essential root-knot nematode parasitism gene. ProcNatlAcadSci U S A. 103: $14302-$ 14306.

Hussey RS, Huang G, Allen R (2011) Microaspiration of esophageal gland cells and cDNA library construction for identifying parasitism genes of plant-parasitic nematodes. Methods Mol Biol. 712:89-107.

Jorgensen RA, Cluster PD, English J, Que Q, Napoli CA(1996)Chalcone synthase cosuppression phenotypes in petunia flowers: comparison of sense vs. antisense constructs and singlecopy vs. complex T-DNA sequences. Plant Mol. Biol. 31:957-973.

Jung C. and U. Wyss, 1999: New approaches to control plant parasitic nematodes. Appl. Microbiol. Biotech. 51: 439-446. 
Li J, Todd TC, Lee J, Trick HN (2011) Biotechnological application of functional genomics towards plantparasitic nematode control. Plant Biotechnol J.9: 936-44

Li X, Zhang M, Zhang H (2011) RNA interference of four genes in adult Bactroceradorsalis by feeding their dsRNAs. PLoS ONE 6: e17788

Lilley CJ,Urwin PE, McPerson MJ, Atkinson HJ(1996) Characterization of intestinally active proteinases of cyst-nematodes. Parasitology113:415424.

McCarter JP, Mitreva MD, Martin J, Dante M, Wylie T, Rao U, Pape D, Bowers $\mathrm{Y}$, TheisingB, Murphy $\mathrm{CV}$ et al., (2003) Analysis and functional classification of transcripts from the nematode Meloidogyne incognita. Genome Biol. 4: R26.

Nadim W,Alkharouf, Vincent P Klink, Benjamin F, Matthews (2007) Identification of Heteroderaglycines (soybean cyst nematode [SCN]) cDNA sequences with high identity to those of Caenorhabditiselegans having lethal mutant or RNAi phenotypes. Experimental parasitology115: 247-258

Novina CD, Sharp PA (2004) The RNAi revolution. Nature. 430:161-4.

Ohtani K, Fujioka S, Kawano T, Shimada A, Kimura Y (2011)Nematicidal activities of 4-hydroxyphenylacetic acid and oidiolactone D produced by the fungus Oidiodendron sp.Z Naturforsch C. 66:31-4.

Parkinson J, Mitreva M, Hall N, Blaxter M, McCarter JP (2003) $400 \quad 000$ nematode ESTs on the Net. Trends Parasitol., 19: 283-286.

Samac DA,Smigocki AC (2003) Expression of Oryzacystatin I and II in Alfalfa Increases Resistance to the RootLesion Nematode. 93:799-804.

Tan JA, Jones MG, Fosu-Nyarko J. (2013) Gene silencing in root lesion nematodes (Pratylenchus spp.) significantly reduces reproduction in a plant host.ExpParasitol. 133:166-78.

Waterhouse PM, Graham MW, Wang MB (1998) Virus resistance and gene silencing in plants can be induced by simultaneous expression of sense and antisense RNA. ProcNatlAcadSci U S A. 95:13959-64.

\section{How to cite this article:}

Shailendra Sharma. 2016. Genomics Approaches Used to Control Plant Parasitic Nematodes A Review. Int.J.Curr.Microbiol.App.Sci. 5(3): 823-828. doi: http://dx.doi.org/10.20546/ijcmas.2016.503.095 